\title{
Bulgarian tshalgavideot, poliittisuus ja orientalismi
}

Musiikkivideo on herättänyt tutkijoiden huomiota uutena taidemuotona ja mediaformaattina, jonka sanotaan muuttaneen ratkaisevasti länsimaisen populaarimusiikin tuotanto- ja markkinointitapoja 1980-luvulta lähtien. Videotuotanto on kytkeytynyt erityisesti rockmusiikkiin, jopa siinä määrin, että rock ja video tuntuvat tarkoittavan välillä samaa asiaa. Tätä symbioosia edustavat näkyvimmin musiikkivideokanavat, joiden talous perustuu mainontaan - niistä tunnetuin on ainakin meillä Music Television, joka leviää satelliitin välityksellä maapallon eri puolille. Rockvideota voikin hyvällä syyllä pitää paljon keskustelua herättäneen globalisaatiokehityksen sanansaattajana musiikin alueella.

Harvemmin tulee mieleen, että musiikkivideolla on nykyisin tärkeä sijansa myös paikallisten ja ei-länsimaisten populaarityylien kehittäjänä ja ylläpitäjänä. Monissa kehitysmaissa videosta näyttää olevan tulossa c-kasettiin perustuvan paikallisen äänitetuotannon jatke tai laajennus. Peter Manuelin $(1993,63)$ tutkimuksen mukaan musiikkivideot eivät kuitenkaan vielä 1980-luvun lopussa näytelleet merkittävää roolia intialaisessa kasettikulttuurissa. Ilmeisesti laitteita ei ollut tarpeeksi - muutenhan intialaisen musiikkielokuvan perinteen luulisi sopivan mainiosti videotuotannon pohjaksi. Silti viitteitä videoiden tulosta myös Intiaan oli jo havaittavissa: niillä oli esimerkiksi kasvava merkitys vaalipropagandan välineenä; vaalivideoita näytettiin ulkosalla erityisten kiertävien videovaunujen suurista kuvastimista (mt., 252).

Tämä kirjoitus tuo esiin toisenlaisen esimerkin paikallisesta videotuotannosta, bulgarialaiset tshalga-videot. ${ }^{1}$ Bulgaria on osa Eurooppaa ja samalla hyvin itäinen maa, jonka kansantalous laski 1990-luvulla lähes kehitysmaatasolle (Suvilehto 1999; Ghodsee 2000, 6-7). Silti Bulgaria ei ole mikään Intia, ja musiikkivideoiden vaatima laitekanta on taloudellisesta ahdingosta huolimatta vähitellen kasvanut - ensin

\footnotetext{
1 Tutkielma perustuu monivuotiseen bulgarialaisen populaarimusiikin harrastukseen. Kiitän lämpimästi seuraavia kollegoja, jotka ovat edesauttaneet tutkimustani matkatovereina, analyysikonsultteina, kielen kääntäjinä ja/tai keskustelukumppaneina: Risto Blomster, Risto Pennanen, Jarkko Niemi, Pekka Jalkanen, Lozanka Pejtsheva, Ilkko Suvilehto, Ventsi Dimov, Ralf Petrov, Antti-Ville Kärjä.
} 
musiikkibaareihin ja muihin huvipaikkoihin ja sitten myös yksityistalouksiin. ${ }^{2}$ Lisäksi vuosikymmenen lopulla yleistynyt kaapelitelevisio on kasvattanut musiikkivideoiden näkyvyyttä. Tätä kirjoitettaessa Sofiassa toimi ainakin yksi kaapelikanava nimeltään ONIX, joka lähetti bulgarialaisia musiikkivideoita tauotta kotitalouksiin ja huvihuoneistoihin (Venci Dimovin tiedonanto 2.4.2001). Omien havaintojeni mukaan tällaista tarjontaa on ollut jo ainakin parin kolmen vuoden ajan.

Bulgarialaisten videoiden analyysissä on erityisen kiintoisaa pohtia, eroavatko ne globaalista MTV-formaatista ja jos eroavat, niin miten. Tutkimusaineistona on joukko musiikkivideoita, jotka on julkaistu Bulgariassa vuosien 1995-2000 välisenä aikana. Bulgarialainen videotuotanto sisältää monenlaista populaarimusiikkia, mutta keskityn seuraavassa vain suosituimpaan lajiin, tshalgaan. ${ }^{3}$

Tshalga on tämän päivän Bulgariassa yleisnimi uudelle tanssimusiikille, joka on syntynyt monenlaisten tyylien sekoittumisen tuloksena. Fuusion aineksia ovat mm. serbialainen, makedonialainen, kreikkalainen ja turkkilainen populaarimusiikki, bulgarialainen vanhempi iskelmä, Balkanin mustalaismusiikin eri tyylit, länsimainen pop, rock, tekno ja rap sekä afrokuubalaisen musiikin globaalit tyylit. Tshalgan tyylikirjo on sen verran laaja, ettei sitä ole helppo määritellä. Kuitenkin tyylin keskiössä on varsin tunnistettava napatanssirytmi sekä eräät muut musiikilliset piirteet, jotka viittaavat Itään, itäisen Välimeren populaarimusiikin valtatyyleihin.

Tshalgan orientaalisuuden tekee ongelmalliseksi se, että koko bulgarialainen kulttuuri on monessa suhteessa länsieurooppalaisen vastakohta. Idän ja lännen välinen raja on siellä häilyvä. Siitä huolimatta tshalgan itämaisuus on jotakin sellaista, johon bulgarialaiset tekevät selvän eron ja joka erottuu myös ulkopuolisen tarkkailijan korvissa bulgarialaisesta kansanmusiikista ja vanhemmista populaarimusiikin tyyleistä. Tämän kirjoituksen keskeisenä tehtävänä onkin pohtia, mitä merkityksiä tshalgan itämaisuus saa bulgarialaisten keskuudessa. Otan yhdeksi lähtökohdaksi saidilaisen orientalismi-tulkinnan, joka on viime aikoina herättänyt jonkin verran kiinnostusta myös suomalaisessa musiikintutkimuksessa (esim. Thiam 1999, 392-394). Epäilen tosin melkoisesti postkolonialistisen kritiikin soveltuvuutta bulgarialaisen populaarimusiikin analyysiin. Yritänkin etsiä vaihtoehtoista tapaa, jolla orientalismin voisi selittää uskottavammin Bulgarian kaltaisessa maassa.

Tärkeänä analyysin kohteena on myös tshalga-videoiden poliittisuus. Toisin kuin bulgarialaisessa kevyessä musiikissa yleensä, monissa tshalga-kappaleissa pistää silmään voimakas yhteiskuntakriittisyys. Bulgarialaisen yhteiskunnan ilmiöitä kommen-

\footnotetext{
2 Toisin kuin Intiassa, laitekanta tarkoittaa Bulgarian kohdalla lähinnä videonauhureita, kaapeliverkkoa ja satelliittiantenneja. Tehokas televisioviestintä oli mm. propagandasyistä jo sosialistisen Bulgarian aikana pitkälle kehittynyttä ja vastaanotinverkko suhteellisen tiheä.

3 Kokoelmassani on yhteensä 40 kasetillista bulgarialaisia musiikkivideoita, joiden kesto vaihtelee puolesta yhteen tuntiin. Olen analysoinut tarkemmin lähinnä Payner-yhtiön hittikokoelmat (1996-2000) ja muutaman johtavan tshalga-laulajan sooloalbumit, joiden sisällössä tshalgamusiikin osuus on hallitseva.
} 
toidaan usein tavalla, joka saattaa saada monen vakavamielisen kulttuurintutkijan pyörittämään päätään. Seksistinen pehmoporno näyttää olevan se keino, jolla videot menevät kaupaksi. Videot sisältävät myös rankkaa huumoria, joka ei tunnu kunnioittavan mitään. Pilkan kohteena ovat niin poliitikot, esivalta, uusrikkaat, mafia, machokulttuuri, seksibisnes, arabisheikit ja länsimaiset muoti-ilmiöt. Ironinen kritiikki voi olla myös niin kätkettyä, että ulkopuolinen ei havaitse sitä lainkaan ilman paikallisen asiantuntijan selitystä. Samalla pilkkaamisen ja ihailun raja voi jäädä hyvin epäselväksi. Kaikesta on kuitenkin vakavuus kaukana ja poliittisesta korrektisuudesta ei näy jälkeäkään.

Postkolonialistinen kritiikki ja poliittinen korrektisuus kuvaavat mielestäni hyvin kriittistä musikologiaa, edellinen tyypillisenä uutena tutkimuskohteena ja jälkimmäinen tutkijoiden kielenkäyttöä säätelevänä normina. Niin sanotun lingvistisen käänteen jälkeen on ilmeisesti päädytty käsitykseen, että diskurssi ratkaisee kaiken. Samalla myös tutkijoiden oma puhetapa on joutunut yhä tarkemman syynin kohteeksi. Aiheeni sivuaa monia postkolonialistisen diskurssin teemoja ja on siltä osin uuden musiikintutkimuksen muodin mukainen. Silti näkökulmaani ei voi varmaankaan kutsua kriittiseksi, koska en pyri parantamaan maailmaa enkä korjaamaan epäoikeudenmukaisiksi leimattuja asenteita. Olen lisäksi vakuuttunut, ettei valkoisen miehen taakalla voi selittää kaikkea maailman vääryyttä. Tshalga-videoiden hullutteleva orientalismi saattaa olla kolonialismin heijastusta, mutta tuon seuraavassa esiin myös muita selitysmalleja tshalga-tyylin syntyyn ja suosioon.

\section{Tshalgan taustoja}

1990-luvulla monet Euroopan jälkikommunistiset maat kokivat kaiken muun yhteiskunnallisen ja kulttuurisen myllerryksen ohessa myös paikallisessa äänitetuotannossaan valtavan muutoksen. Kehityksen keskeisiä ilmiöitä olivat laaja paikallinen kasettituotanto sekä erityisesti ulkomaisen musiikin piraattikauppa. Piraattituotanto alkoi kaseteilla, mutta siirtyi hyvin nopeasti cd-formaattiin. Tuotannon ydinalueet ovat vaihdelleet aina sen mukaan, miten USA, EU ja kansainvälinen äänitetuottajien järjestö IFPI ovat ulottaneet piratismin vastaisia kampanjoitaan liian räikeiksi katsottuihin tapauksiin. $\mathrm{Ne}$ ovat painostaneet paikallisia hallituksia poliisitoimiin ja tiukentamaan lainsäädäntöään. Aluksi Itä-Euroopan piraattituotannon keskuksia olivat Puola ja Bulgaria, sitten Viro ja Romania ja nyttemmin Ukraina. Myös Venäjä on hankkinut paljon kyseenalaista kunniaa tällä alueella. ${ }^{4}$ (Music industry... 1999; IFPI... 2000; Kurkela 1997, 183-184.)

\footnotetext{
${ }^{4}$ IFPI:n piratismin vastainen toiminta on saavuttanut vain osittaisia voittoja. Vaikeinta on maissa, joissa harmaa talous on muutenkin häkellyttävän laajaa. Niinpä kaikissa luetelluissa valtioissa piratismin osuus kotimaan tuotannosta on vieläkin vähintään 50\%; Venäjän piraattiasteen arvioidaan olevan 75\% äänitetuotannosta.
} 
Monessa entisen itäblokin maassa kehitys on merkinnyt länsimaisen populaarimusiikin aseman vahvistumista. Halvat piraattikopiot ovat levittäneet länsihittejä tehokkaasti, ja paikallinen äänitetuotanto on kärsinyt pääomien ja markkinoiden puutteesta. Bulgaria näyttäisi kuitenkin olevan toista maata. Siellä on ollut havaittavissa varsinkin 1990-luvun puolivälin jälkeen todellinen kotimaisen tanssimusiikin buumi, jonka keskiössä oli orientaalinen tshalga. Tshalga-innostuksen voi tulkita jonkinlaiseksi protestiksi 1980-luvun kommunistiselle kulttuuripolitiikalle. Se perustui monoetniseen näkemykseen, jossa kaikki Bulgariassa asuvat selitettiin bulgarialaisiksi ja vähemmistöjen olemassaolo pyrittiin kieltämään. Vaino kohdistui etupäässä muslimivähemmistöihin, joiden kulttuuri ja tavat poikkeavat eniten bulgarialaisesta valtakulttuurista. Bulgariassa on kolme muslimiuskoista vähemmistöryhmää, pomakit, turkkilaiset sekä (osittain) mustalaiset, joista varsinkin turkkilaiset joutuivat 1980-luvulla voimakkaan ja väkivaltaisen diskriminoinnin kohteeksi. Asiaan liittyi mm. nimien pakollista bulgarialaistamista, väestönsiirtoja ja maasta karkotuksia. (Poulton 1991, 129-151.)

Vähemmistöjen omaan kulttuuriin kuuluvat erityispiirteet pyrittiin myös tukahduttamaan, ja musiikki sai tästä tietenkin osansa. Niinpä turkkilaisuuteen ja mustalaisuuteen yhdistyvä itämaisväritteinen tanssimusiikki oli käytännössä pannassa (Buchanan 1996, 207-212; Pennanen 2001). Kommunistihallinnon romahtaminen 1990-luvun taitteessa merkitsi myös kulttuuripolitiikan muutosta. Uuden ajan yksi näkyvä ja kuuluva ilmaus oli tässä käsiteltävä itämaisvaikutteinen populaarimusiikki ja sen valtava suosio.

Balkan on täynnä paradokseja ja myös tässä tapauksessa orientaalipopin esikuvat tulivat aluksi idän sijasta lännestä ja etelästä, Serbiasta ja Kreikasta. Varsinkin ennen hajoamistaan Jugoslavia oli tiennäyttäjä uudenlaiselle paikallisperinteisiin tukeutuvalle populaarimusiikille (novokompanovana narodna muzika), joka levisi pääasiassa piraattikopioina myös Bulgariaan jo kommunistihallinnon aikana. Samalla tapaa kuin Jugoslavia oli etninen tilkkutäkki, myös novokompanovana-termin alle mahtui hyvin erilaisia musiikillisia tyylejä. Bulgarialaiset pitivät erityisesti serbialaisesta folkpopista sekä kreikkalaisesta laikasta. (Dimov 1996, 31-33.)

Vielä 1990-luvun alussa tshalga tarkoitti Bulgariassa pääasiassa mustalaisten esittämää tanssimusiikkia. Vastaavasti Turkin Euroopan puoleisessa osassa, Rumeliassa ammattimaisia mustalaisbändejä kutsutaan edelleenkin nimellä çalgıct ja Makedoniassa kyseinen termi on tshalgija (Seeman 2000, 7-11; Silverman 1996, 71-72). Nimitykset perustuvat turkin kieleen, jossa çalgı tarkoittaa mm. soitinta. Näiden yhtyeiden historia ulottuu jo osmanikaudelle, jolloin ne esittivät mm. turkkilaista klassista ja kevyttä musiikkia. Historialliset makam-juuret näkyvät nykyisinkin siinä, että uudenaikaisen sähkösoittimilla varustetun tshalgijan ohjelmistossa on runsaasti napatanssikappaleita (tshotshek), joille on tyypillistä pitkät vapaarytmiset ja kappaleen modaliteeteissa liikkuvat improvisoidut soolo-osuudet. 
Myös Bulgariassa tshalga-tyyli tuli aluksi tunnetuksi juuri näistä samoista kjutshekkappaleista ${ }^{5}$, joille on ominaista mm. nelijakoinen tai 9/8-napatanssirytmi, pitkät klarinettisoolot ja usein mustalaiskieliset sanoitukset. Monet kjutshekit ovat pelkkiä instrumentaaleja, joissa lyhyttä teemaa seuraa lähes loppumaton solistinen taiturointi. Oman kasettikokoelmani perusteella juuri tässä musiikissa oli kaikkein säröisin sointi ja huonoin tekninen laatu. Särösaundinen mustalaismusiikki oli myös kaikkea muuta kuin arvostettua keskivertobulgaarien keskuudessa.

Tuossa vaiheessa mustalaiskjutshekilla oli vielä varteenotettava kilpaileva tshalgatyyli. Traakialaista häämusiikkia (svatbarska muzika) soittavat yhtyeet olivat suosionsa huipulla. Tunnetuinta solistia, klarinetisti Ivo Papazovia, pidettiin melkein kansallissankarina. Vaikka myös traakialaismuusikot olivat monesti mustalaisia ja/tai turkkilaisia, svatbarska oli lähes kaikessa suhteessa parempaa ja arvostetumpaa kuin kjutshek: ammattimaisesti esitettyä, paremmin äänitettyä, äärimmäisen virtuoottista, hengästyttävän svengaavaa, värikkään orientaalista ja vieläpä vanhan vallan vastustajien symboli. (Buchanan 1995, 387; 1996, 204-206.) Häämusiikissa oli vain yksi vika. Se oli kehittynyt omassa virtuoosisuudessaan niin monimutkaiseksi ja nopeatempoiseksi, ettei siitä oikein ollut tanssimusiikiksi. Kaupallisen menestyksen puutteessa myös osa traakialaisista hääsoittajista siirtyi 1990-luvun kuluessa tshalgan mainstreamiin ja tanssittavimpiin napatanssirytmeihin.

1990-luvun alkuvuosina tapahtui hyvin kiintoisa kehitys, jonka kuluessa mustalaiskjutshek fuusioitui bulgarialaisten aiemmin suosimaan serbialais- ja kreikkalaisvaikutteiseen folkpopiin ja otti samalla lisää vaikutteita sopivista kansainvälisistä tyyleistä ja artisteista (mm. Gypsy Kings). Tätä uutta kokonaisuutta alettiin kutsua nimellä tshalga, joka aiemmin oli ollut pelkkä haukkumanimi tai yleisnimi kaikelle huonolle ja ala-arvoiselle, mustalaiskulttuuriin liittyvälle. Tshalgan kehitys muistutti monessa suhteessa Jugoslavian novokomponovanan muutosta kymmenen vuotta aiemmin. Myös Jugoslaviassa mustalaisten orientaalinen saundi ja aina Intiasta saakka lainatut kansainväliset hittikappaleet nousivat 1980-luvun kuluessa suureen suosioon ja vaikuttivat uudenlaisen, orientaalisia stereotypioita hyödyntävän yleistyylin kehittymiseen. Kuten jo mainitsin, tällä kaikella oli vaikutuksensa myös uuden bulgarialaisen populaarimusiikin kehitykseen. (Rasmussen 1991, 128-132).

Uudesta tyylistä tuli eittämätön menestys bulgarialaisessa populaarimusiikissa. Suosituimmat tshalga-hitit myivät yli 100 000, kun esimerkiksi paikallinen rockmusiikki ylti parhaimmillaankin vain 10 000-15 000 myytyyn äänitteeseen. (Ivo Dotshovski, Ventsi Dimov haastattelut 1999)

Kaupallinen menestys nosti huomattavasti tshalgan arvostusta bulgarialaisessa jul-

Sekä bulgarialaisen että makedonialaisen napatanssin nimi tulee turkinkielen termistä köçek, joka viittasi alun perin osmanihovin nuoriin poikatanssijoihin ja nykyisin yleensä napatanssiin. (esim Feldman 2000, 4-11). 
kisuudessa. Sen sanotaan olevan nimenomaan uuden taloudellisen yläluokan, uusrikkaiden musiikkia - minulle on tosin jäänyt kovin epäselväksi mihin tämä väite perustuu, ehkä siihen, että tshalga-laulut kuvaavat usein jetset-elämää ja unelmia läntisestä hyvinvoinnista. Tshalga-konserttien yleisön perusteella innokkain kannattajakunta on joissakin nuorisoryhmissä ja - yllättävää kyllä - myös lasten ja varhaisnuorten keskuudessa. Onpa nähty sellainenkin ihme, että eräät perinteisen kulttuurieliitin jäsenet ovat ilmaisseet kiinnostuksensa tshalga-ilmiöstä. Heidän kiinnostuksensa kohdistuu lähinnä siihen, miten ihmeessä tällainen musiikki - tai näin "huono musiikki" voi saavuttaa niin valtavan suosion. ${ }^{6}$

Tavallisempi akateeminen asenne näyttää kuitenkin pysyttelevän kommunistikauden kulttuurieliitin linjalla. Asennetta heijastaa vakuuttavasti kirjallisuudentutkija Julia Stefanovan (i.v.) kommentti kulttuurin "tshalgasoitumisesta"; termi tarkoittaa alinomaista tunnetta siitä, miten bulgarialainen kulttuuri "on vajoamassa alakulttuuriksi ja korvikkeeksi". Tshalgan katsotaan myös peilaavan uuden taloudellisen yläluokan kykenemättömyyttä luoda itselleen vakavasti otettavaa kulttuurista legitimiteettiä (Kessi 2001, 5). Amerikkalainen feministinen tulkinta tshalgasta lähtee puolestaan siitä, että laulujen piilopornoinen erotiikka esittelee bulgarialaiset naiset kunnianhimoisina mutta aivottomina bimboina ja edistää samalla sitä sukupuolten välistä epätasa-arvoa, joka Bulgariassa on tutkimusten mukaan voimakkaasti lisääntynyt siirtymätalouden aikana (Ghodsee 2000,10). Tshalga tuntuu näin jakavan mielipiteitä ja nostattavan tunteita. Vaikka tämä puoli tshalgan poliittisuudesta jää seuraavan analyysin ulkopuolelle, se on hyvä pitää mielessä myös tshalga-laulujen olemusta mietittäessä.

\section{Tshalgan itämaisuus}

Tshalgan yhdistäminen orientalismiin edellyttää, että siitä voi osoittaa itämaisia piirteitä, liittyivät ne sitten itse musiikkiin, lauluteksteihin tai videon kuvakerrontaan. On heti sanottava, että itämaisuus on yleensäkin orientalistisessa taiteessa perin häilyvä ja suhteellinen ominaisuus. Orientalismi on yleisimmän määritelmänsä mukaan kuviteltua itämaisuutta ja Idän representaatiota länsimaisessa kulttuurissa; se ei ole toisen kulttuurisen käytännön köyhää imitaatiota, sen tarkoitus ei ole jäljitellä vaan edustaa (Scott 1997, 9). Niinpä itämaisuus voi yhtä hyvin olla täysin keksittyä kuin perustua johonkin Orientin esikuvaan. Pääasia on, että vastaanottajat tunnistavat orientaalisen merkitsijän, joka useimmiten kaavoittuu yhteiseksi Itä-kokemukseksi. Esimerkiksi 1700-luvulla eurooppalaiset säveltäjät saattoivat viitata turkkilaisuuteen C-duuri-

6 Tämä käsitys perustuu paitsi paikallisten asiantuntijoiden haastatteluihin (Ventsi Dimov, Rozmari Statelova 1999), myös omiin kokemuksiin tshalga-konserttien yleisöstä vuosina 1997-2000). 
asteikolla, mutta myös nopeilla duurin ja mollin vaihdoksilla, yllättävällä kromatiikalla ja erityisesti rummun paukkeella ja symbaalien räminällä (MacKenzie 1995, 142).

Tshalgan kohdalla orientaalisten kaavamaisuuksien etsintää sotkee se kiistämätön tosiseikka, että länsimaisen kuulijan korvin bulgarialainen musiikki on jo sinänsä itämaista, niin melodisesti, rytmisesti kuin soinnillisesti. Melko varmalta näyttävän ulospääsyn tästä kysymyksestä tarjoaa tshalgan vankka mustalaistausta. Siitä seuraa, että bulgarialainen yleisö rakentaa myös nykyisen tshalgan itäisyyden pääasiassa mustalaismusiikkiin liittyvien mielikuvien avulla. Siitä seuraa edelleen, että tshalgan itäiseksi tulkittu saundi pohjautuu mustalaismuusikkojen välittämään orientaaliseen sointimaailmaan. Mustalaismuusikot ovat toimineet vuosikymmeniä yleisorientaalisen, itäisen Välimeren alueella vallitsevan populaarimusiikin sanansaattajina kaikissa Balkanin maissa (Vrt. Pettan 1996, 37-41). Tämä kannattaa ottaa huomioon, kun alkaa tulkita tshalgan itäisiä piirteitä niin musiikin, videokuvien kuin mielikuvienkin tasolla.

Vähiten viittauksia orienttiin on tshalgavideoiden lauluteksteissä, oikeastaan vain niissä tapauksissa kun video on paikallistettu itäiseen ympäristöön. Tällöin orienttikonteksti ilmenee jo teoksen nimessä, kuten "Kapali tsharsija" (Istanbulin suurin basaari), "Metshtata na sheiha" (Sheikin uni), "Harema" (Haaremi) tai Ali Baba. Tshalga-laulujen kokonaismäärästä nämä muodostavat vain murto-osan. Tämä havainto kertoo jotain hyvin olennaista tshalgan orientaalisuudesta. Tshalga ei pyri ainakaan suoraan osoittelemaan aiheillaan itämaille, vaan orienttiviite on lähes aina epäsuorempi ja sekoittunut täysin muihin asioihin.

Videon kuvakerronta suosii silti jo huomattavasti enemmän myös suoria itämaisia viitteitä. Varsin monen videon lavasteena on sokkeloinen pylväikkö, turkkilaista saunaa muistuttava kylpylärakennus tai värikkäästi koristeltu ravintolasali, jotka kaikki viestivät kuvitteellista Orienttia. Toisaalta näiden ympäristöjen vastapainoksi tshalgavideot hyödyntävät nykyajan mediajulkisuuden synnyttämiä mielikuvia ja mielen maisemia, joita olen toisessa yhteydessä kutsunut termillä "moderni eksotiikka" (Kurkela 1996, 46). Klassisten orienttikuvien rinnalla ovat nykyajan sankarit ja antisankarit ja heidän temmellyskenttänsä: mafiapomot saksalaisine loistoautoineen, seksikkäät valokuvamallit muotivaatteissaan sekä huolettomat uusrikkaat viettämässä leppoisaa rantaelämää Mustanmeren rannalla. Yhtä kaikki myös nämä mielikuvat ovat usein yhtä etäisiä tavalliselle bulgarialaiselle kuin itämaan aarteet, haaremien neidot ja pullon henget.

Klassisista orienttiaiheista ehkä silmiinpistävin on "itämaisen" tanssin osuus. Itämaisuuden sijasta on tässäkin yhteydessä oikeampaa puhua tanssin orientalismista, jossa itämaisuus tuodaan esiin sekä kuvitteellisten että todellisten Itä-viitteiden avulla. Kuvitteellista Orienttia edustavat mm. tanssiryhmät, jotka on kiinnitetty kuvauksiin bulgarialaisista huippuluokan turistipaikoista. Tanssiryhmien tyyli on usein fuusio länsimaisesta revyyperinteestä ja sosialistisesta folklorismista ja tyylin itämaisuus liittyy enemmän koristeelliseen rekvisiittaan kuin koreografiaan. Ryhmien tanssijat eivät esi- 
merkiksi kohdista liikesarjoja lantion ja vatsan alueelle vaan raajoihin - näytökset saattavat sisältää mm. can-can -tyyppistä jalkojen nostoa.

Enemmän turkkilais-arabialaista napatanssia muistuttava tanssityyli on myös kuulunut tshalga-videoiden kuvalliseen repertuaariin aivan videotuotannon alkuajoista lähtien. Kehitys "aidompaan" suuntaan on ollut huomattava. Vanhin tutkimusaineistoon kuuluva video Knezha-yhtyeen "Sheikin uni" (Lazarov-records 2, päiväämätön tuote 1990-luvun alkupuolelta) esittelee sheikki-aiheeseen sopivan huntutanssin, jossa kaksi pitkähköä rouvaa ravistelee itseään kjutshek-rytmin tahdissa. Koreografiassa napatanssiin viittaavat vain käsien sirot liikkeet. Tanssijoiden vartalo on varsin jäykkä, lanne ei juuri liiku ja viimeistään tanssijoiden korkokengät paljastavat, että kyseessä varsin kuvitteellinen napatanssiesitys.

Vuosina 1995-1996 ilmestyi jo useita videoita, joihin oli saatu kiinnitetyksi napatanssiperinteessä kiinni olevia tanssijoita. Piikkarit ovat saaneet väistyä matalien tossujen tieltä tai tanssijat ovat paljasjaloin. Tanssijoiden vatsan seutu on hyvin kehittynyt ja lantion liikkeissä on sellaista potkua, että sen saavuttaminen on vaatinut pitkäaikaisen koulutuksen. Tällaisia esimerkkejä on mm. yhtyeiden Kozari, Kristal ja Juzhen polàh videoilla, joskin aina välillä pääosassa on kuvitteellista napatanssia esittävä artisti. Tshalgan orientalismissa todellinen ja kuvitteellinen muodostavat kiehtovan kudoksen, jonka autenttisuutta on turha yrittää määritellä.

Sama kiehtova kudos tulee esiin itse musiikissakin. Bulgarian musiikin kontekstissa on vaikea vetää itämaisuuden rajaa musiikin saundin perusteella, mikä metodi toimii huomattavasti paremmin klassisen länsimaisen musiikkiorientalismin kohdalla. ${ }^{7}$ Syynä on tietenkin jo mainittu Bulgarian musiikin oma itäinen vivahde, joka kuuluu mm. perinnesoittimien soinnissa sekä lauluun ja soittoon kiinteästi liittyvässä koristelutekniikassa. Kansanmusiikissa käytettävät luuttusoittimet, huilut tai klarinetit eivät juuri eroa soinniltaan itäisemmistä tai eteläisemmistä vastineistaan, ja niinkin länsimainen soitin kuin harmonikka on omaksunut mm. paikallisista säkkipillitraditioista sellaisia fraaseeraus- ja koristeidenkäyttötapoja, jotka tekevät bulgarialaisesta haitarinsoitosta sangen omaperäisen keskieurooppalaiseen tai venäläiseen soittotyyliin verrattuna.

Itämaisuuden musiikillisia merkkejä onkin syytä etsiä sellaisista kaavamaisuuksista, jotka näyttäisivät kuuluvan lähes jokaiseen tshalga-lauluun, mutta joita ei tavata tai jotka eivät ole ainakaan tyypillisiä muulle bulgarialaiselle kansan- ja populaarimusiikille. Ensimmäinen piirre on ilman muuta napatanssirytmi. Tämä tavallisesti neli-

\footnotetext{
7 Esimerkiksi pianolla soitettu alkusoitto Carl Maria von Weberin oopperasta Abu Hassan (1800) tai vieläkin tunnetumpi Mozartin Turkkilainen marssi (pianosonaatti nr. 9, K. V. 300) on helppo tunnistaa eurooppalaisen taidemusiikin itäkuvitelmaksi, jolla on kovin vähän tekemistä tuon ajan itämaisen musiikin kanssa. Tosin tällaista jälkikäteisarviota rajoittaa se, ettei ole tarkalleen tiedossa millaiseksi 1700-luvun lopun eurooppalaiset kuvittelivat turkkilaisen tai arabialaisen musiikin. Yhtä huonosti tiedetään sekin, miltä turkkilainen tai arabialainen tuolloin oikeasti kuulosti.
} 
jakoinen rytmikaava hallitsee suurinta osaa aineistoa. ${ }^{8}$ Olennaista siinä on ykköstä ja kolmosta korostava pääisku ja sille vastakkaiset väli-iskut toiselle ja neljännelle kahdeksasosalle sekä neljännelle neljäsosalle. Erityisen keskeinen synkopoiva isku on neljäs kahdeksasosa. Ilman sitä napatanssirytmiä ei voi identifioida, enkä ole havainnut että se jäisi koskaan pois edes kaikkein pelkistetyimmistä komppiversioista. Toisaalta myös neljännen neljäsosan korostaminen on olennaista tshalgan modernisaatiolle. Se toimii siemenenä tämän rytmikaavan fuusioimiseen mm. kuubalaisperäisiin rytmistandardeihin (Esim. 1).

Esimerkki 1. Tasajakoinen kjutshek-rytmi.

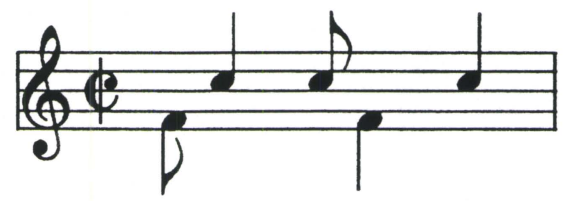

Tshalga-laulujen tempot ovat enimmäkseen verraten verkkaisia (M. M. 80-85), mikä on omiaan vahvistamaan rytmisen synkopoinnin tehoa. Tasaisesti etenevä mutta synkopoiva komppi on tehokas lanteen keinuttaja, mitä sen pitkäaikainen suosio koko itäisen Välimeren alueella todistaa.

Varsin yksinkertainen rytmikaava on kahdellakin tavalla otollinen tshalgan suosiolle ja kehitykselle. Ensinnäkin se eroaa ratkaisevasti bulgarialaisen kansallisen musiikin additiivisista rytmeistä, jotka ovat jonkinlainen bulgarialaisuuden tavaramerkki niin perinteisissä horoissa kuin kansanlauluissakin. Yksinkertaisuus on tshalgan tapauksessa distinktion tae. Se auttaa pitämään tyylillistä etäisyyttä vanhakantaisempiin tanssisävelmiin. Toisaalta napatanssirytmi on hyvin yleinen kaikissa itäisen Välimeren populaarityyleissä, minkä vuoksi tshalgakin saa kansainvälisen ja uudenaikaisen leiman. Lisäksi napatanssirytmi helposti muunneltava, joten se soveltuu mitä erilaisimpiin fuusioratkaisuihin.

Toinen kaavamainen orientaalisuuden merkki näyttää olevan laulujen melodiikka. Tshalgan melodioissa on kaksi tyyppiä, joita suurin osa lauluista noudattaa. Nämä melodiat sisältävät alennetun toisen asteen, joka voi esiintyä joko mollimuotoisena fryygisenä tai duurimuotoisena hicaz-moodia muistuttavana sävelrakenteena. Nämä moodit kyllä tunnetaan perinteisessä bulgarialaisessa kansallismusiikissa, mutta kuten Donna Buchanan $(1995,402)$ hicazin osalta toteaa, perinneorkesterien muusikot leimasivat tämän moodin käytön epäaidoksi turkkilaisuudeksi ja mustalaisuudeksi. Leimakirves heilui varsinkin silloin, jos melodialinja junnasi itsepäisesti alemman tetrakordin sävelissä. Näin suhtauduttiin erityisesti sellaisiin teoksin, jotka sekoittivat

8 Tosin myös länsimaisen kuulijan kannalta eksoottisempi 9/8-rytmi on säilynyt sitkeästi tshalgarepertuaarin osana. Bulgarialaisille se ei ole sen vaikeampi tanssia kuin tasajakoinen komppi. 
eri alueiden ja perinteiden sävelmiä toisiinsa. Tshalgassa eri perinteiden tietoinen sotkeminen näyttää olevan koko estetiikan perusta.

Laulut pohjautuvat hyvin usein säkeistö-kertosäe -rakenteeseen. Säkeistöosassa harmoniapohja on tyypillisesti yksisointuinen, ja melodia korostaa hicaz-tetrakordin intervalleja. Toinen yleisesti käytetty ratkaisu perustuu kolmeen sointuun, jotka kiertävät finalista ja korostavat alennettua toista astetta: I-IIb-vii-I. Samankaltainen sointukierto esiintyy myös fryygisissä kappaleissa (i-IIb-vii-i). ${ }^{9}$ Kertosäe kontrastoi edelliseen siten, että sointupohja rakentuu usein neljän soinnun kierrolla iv-IIIb-IIbI, jolloin myös hicazia muistuttava melodia muuttuu hetkeksi fryygiseksi - tshalgalauluille tyypillisen sekvenssikulun yhteydessä. Tämä säestyskaava kuuluu kansainvälisen mustalaismusiikin perusratkaisuihin, flamenco-perinteessä sitä kutsutaan nimellä cadencia andaluza (Huotari 1999, 105). Sen yleisyys tshalgassa korostaa omalta osaltaan uuden bulgarialaisen hittimusiikin fuusioluonnetta (Esim. 2).

Esimerkki 2. "Levovete v marki" (es. Sashka Vaseva, Pajner Hit Video 2 (Payner 97016), laulumelodia ja sointusäestys.
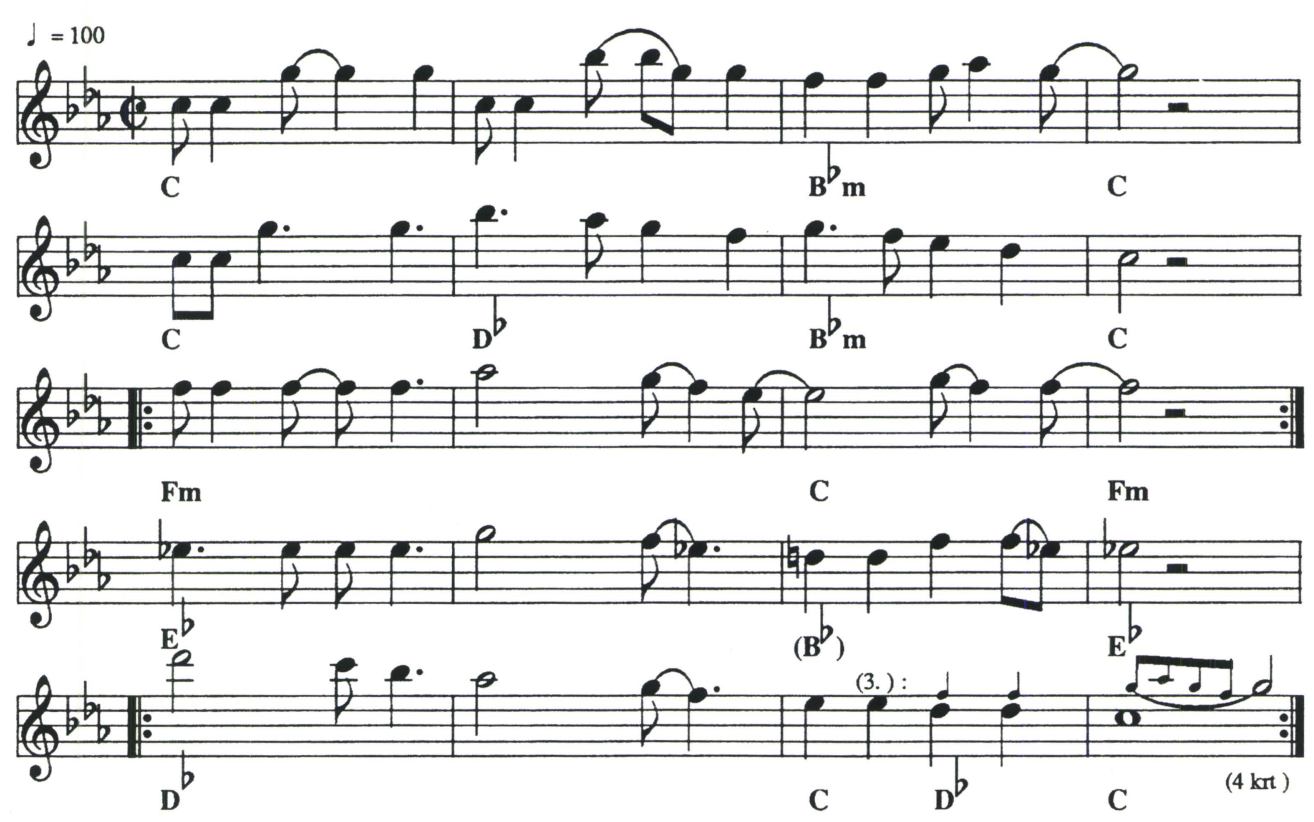

Se mikä hicaz-sävelmissä lisää kertosäkeen kontrastoivaa luonnetta on koko toonikasuhteen häilyvyys. Samalla kun harmonia siirtyy tetrakordin neljännelle asteelle, käy

9 Vrt. Pennanen 1999, 105-118, jossa on selostettu laajemmin ja perusteellisemmin makam-pohjaisten modaliteettien soinnutusta kreikkalaisen populaarimusiikin esimerkkien avulla. 
ilmi, että kappaleen toonika onkin ko. neljäs sävel, ja se alussa määrittynyt finalis, jonka ympärillä melodia liikkuu säkeistöjaksossa, onkin dominanttisävel. Näin koko hicaz-vaikutelma rakentuukin harmoniselle mollille ominaisesta intervallirakenteesta, jossa mollin 6. ja 7. asteen väli on 11/2 sävelaskeleen pituinen. Tämä tulkinta vastaa täysin myös länsimaista harmoniaoppia, ja ehkä tähän liittyen monet konservatoriokoulutuksen saaneet lauluntekijät suosivat kertosäkeen soinnutuksessa barokkimusiikista ja länsimaisesta iskelmästä tuttua kvinttikiertoa. Esimerkiksi tshalga-hitissä Menteta, menteta Kiril Lambovin soinnutusratkaisu vakiinnuttaa toonikan takuuvarmasti hicaz-tetrakordin neljännelle sävelelle. Samalla sekvenssin edetessä sointukierto poistaa tilapäisesti melodian hicaz-luonteen (Esim. 3.).

Esimerkki 3. "Menteta, menteta", laulumelodia ja sointusäestys (nuotinnos: Jarkko Niemi).
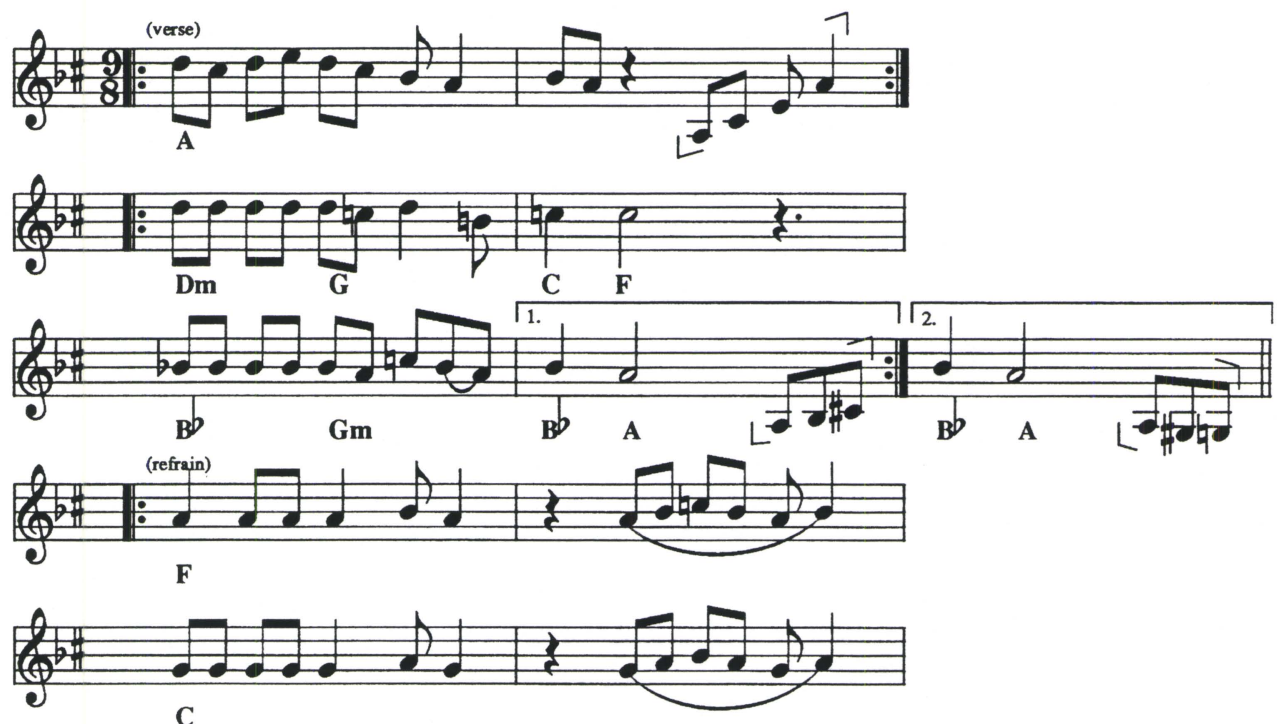

C
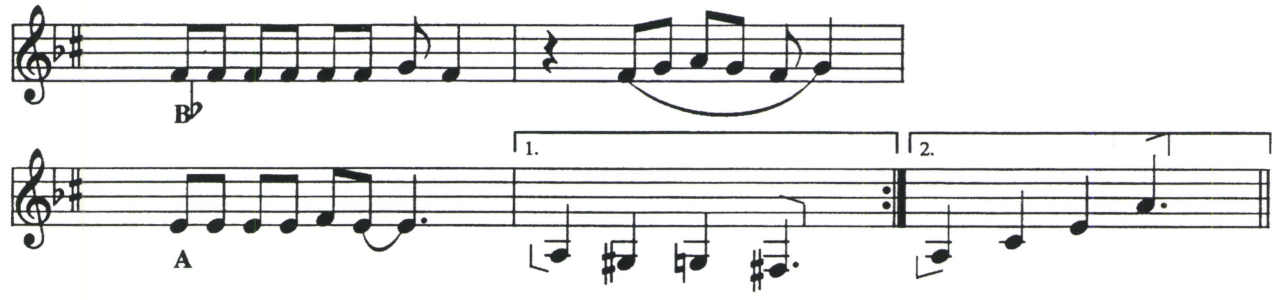

Kolmas musiikillinen orienttimerkki on tshalga-lauluissa käytettävä syntetisaattorisaundi. Sen on helppo tunnistaa; vanhanaikaiselta kuulostava sointi toistuu varsin samanlaisena yhtyeestä toiseen. Syntetisaattorin tärkein tehtävä on tuottaa laulun keskiosan itämainen 'puhallinsoolo'. Sellainen kuuluu jokaiseen lauluun, lähes poikkeuk- 
setta. Ujeltava syntikka myös erottaa itämaisväritteisen tshalgan selvästi muusta bulgarialaisesta iskelmästä, jota myös markkinoidaan tshalga-hittien rinnalla kokoelmakaseteilla. Nämä romanttisesta rakkaudesta kertovat laulut ovat saaneet vaikutteita paikallisen populaarimusiikin vanhemmasta tyylistä (starogradski pesni). Niissäkin käytetään syntetisaattoria, mutta sointimaailma on varsin erilainen - jäljittelyn kohteena voivat olla mm. viulusektio, huilu ja muut länsimaisen viihdeorkesterin saundit.

\section{Tshalga-videoiden tyypittelyä}

Karkeasti ottaen tshalga-videoista voi erottaa kolme perustyyppiä, jos niitä tarkastelee kuvallisen sisällön kannalta: konserttitaltioinnit, narratiiviset videot ja musiikkilähtöiset videot. Jako syntyi mielessäni hyvin spontaanisti, mutta se näyttää seurailevan ainakin varhaisempien läntisten videotuottajien jaottelua. Simon Frithin $(1988,217)$ mukaan ääniteyhtiöt jakoivat rockvideot jo 1980-luvulla kolmeen ryhmään, esittäviin, kertoviin ja käsitteellisiin. Muunlaisiakin jaotteluja on tietysti esitetty (esim. Alanen \& Pohjola 1992, 57), mutta ne ovat etupäässä kuvallisen viestinnän tutkijoiden luomuksia - onhan video ollut postmodernin tutkijoiden lempiaihe. Niissä oletetaan, että musiikki olisi videon renki eikä vaikuta ratkaisevasti taiteelliseen lopputulokseen. Minä puolestani lähden siitä, että musiikki on musiikkivideon isäntä, joka vaikuttaa pitkälle siihen, millä tavoin video rakentuu kuvallisesti. Niinpä myös kuvallisen sisällön jäsentelyn on perustuttava kuva-musiikki-suhteen analyysiin.

\section{Konserttitaltiointi}

Hyvin monia tshalgavideoita voi kutsua konserttitaltioinneiksi. Ne ovat tyylillisesti kaikkein vanhimpia ja nykyisen videokielen näkökulmasta sangen vanhanaikaisia. Esitys korostaa muusikkojen asemaa musiikin tekemisessä ja on monessa suhteessa dokumentaarinen: videon pääsisältönä on musiikkiesityksen konkreettinen kuvaus, jota saatetaan monipuolistaa maisemia tai yleisön reaktioita valottavilla inserteillä.

Tshalga-videoissa konserttitaltiointi näyttää olleen suosituin tuotantomalli traakialaisten hääorkesterien ja eräiden (muiden) mustalaisbändien levytyksissä (mm. Kristal, Kristali, Kitka). Esiintymispaikan ei aina tarvitse olla normaali 'stage': yökerho, konserttisali tai diskoteekki. Monesti tuntuu siltä, että videon tekijät ovat etsimällä etsineet erikoisia ja jopa absurdeja esiintymislavoja. Niinpä esimerkiksi Kitka-yhtyeen musiikkivideo 'Seksi' on kuvattu Mustanmeren rantavedessä, jossa yhtyeen jäsenet seisovat polviaan myöten ja ovat kovasti soittavinaan. Edes sähkörumpujen soittaja ei tunnu pelkäävän veden aiheuttamaa oikosulkua, vaan roiskii menemään aaltojen loiskeessa.

Tähän videotyyppiin kuuluvat luonnollisesti myös erilaiset festivaalivideot, joita 
on tuotettu vuosittain monista popfolkin massatapahtumista (mm. Trakia-folk, Pirinfolk). Ne ovat mitä suurimmassa määrin dokumentin luonteisia. 1990-luvun loppupuolella tekninen kehitys johti siihen, että yhä useampi artisti alkoi tehdä myös liveesityksiä ilman orkesteria, taustanauhan säestämänä. Tämä ei kuitenkaan ole lopettanut konserttivideoiden tuotantoa. Lukuisat laulajat suosivat vieläkin playbackkonserttien taltiointeja musiikkivideoissaan. Orkesterin puuttuminen on korvattu mm. ryhmissä tapahtuvina napatanssiesityksinä; myös artistin ja yleisön välistä vuorovaikutusta saatetaan kuvata enemmän ja monipuolisemmin kuin vanhempityylisissä orkesterisoittovideoissa.

\section{Narratiivinen video}

Kaksi muuta tshalga-videoiden tuotantotyyppiä ovat huomattavan lähellä MTVformaattia, josta näyttăä tulleen lähes pakollinen esikuva koko maailman videotuotannolle. Kutsun niitä seuraavassa narratiiviseksi videoksi ja musiikkilähtöiseksi videoksi. Narratiiviselle tyypille on luonteenomaista, että video koostuu kahdesta tai kolmesta erillisestä kuvakohteesta, joista yksi on videon tarina. Se on kertomuksellinen kokonaisuus, joka liittyy kiinteästi tai löyhästi (yleensä ei kovin kiinteästi) laulutekstiin. Tarinan päähenkilö voi olla laulaja itse, mutta aivan yhtä hyvin jokin näyttelijä. Toisena kuvakohteena on joka tapauksessa itse laulaja, jolloin hänen tehtävänsä on pelkästään laulun esittäminen ilman draamallista yhteyttä videon tarinaan. Kolmas elementti koostuu esimerkiksi tanssijoista tai ympäristökuvista, jotka nekin ovat aika irrallaan videon kuvakertomusosuudesta.

Esimerkkinä löyhästä kuvallisesta tarinasta on laulajatar Petran video Danàtsi (Verot) vuodelta 2000. Lievästi populistinen teksti koostuu pelkästä luettelosta, jossa taivastellaan erilaisten verojen määrää ja veroista hyötyjiä. Asiat on kuitenkin esitetty humoristisesti yllättäviä vastakohtia hyödyntäen:

Veroja rakijasta, veroja naapurin rouvasta, veroja autosta, veroja naisista, veroja roskista, veroja mezestä, veroja meren rannalla oleskelusta - -veroja punikeille, veroja vihreille, veroja sinisille, veroja pingviineille, veroja oliiveista, veroja bikineistä, veroja kerjäämisestä, veroja jonninjoutavasta.

Kertosäe kiteyttää laulajan sanoman:

Verot, verot / te rasvaiset juustopiiraat / te poltatte minut / te saatte minut perikatoon.

(käännös: Ilkko Suvilehto)

Laulun melodia on fryyginen ja harmonia perustuu pelkästään h-mollisoinnulle. Kertosäe kontrastoi aiemmin esitetyllä tavalla, jolloin säestys perustuu subdominantilta alkavaan laskevaan sointukulkuun e-D-C-h. Tshalga-tyylin mukaisesti teoksen keskellä on trumpettia jäljittelevä, koristeleva ja polveileva syntikkasoolo, jonka harmoninen säestys perustuu jälleen pelkkään $\mathrm{h}$-mollikolmisointuun. 
Videon kuvakertomus perustuu parodiaan, jossa viranomaisten veronkanto on laitettu kahden koppalakkisen miliisin tehtäväksi. Heti alussa tarinan sankari on kimpaantunut rikkinäiseen autoonsa ja potkii sitä kylkeen. Miliisit tulevat paikalle ja sakottavat autoilijaa poistuen sitten tyytyväisinä paikalta ylisuurta taskulaskinta näppäillen. Sitten sankari istuu ravintolassa tyttöystävän kanssa, liehakoi tätä, nostelee maljoja ja napostelee mezeä. ${ }^{10}$ Jokaisen kohtauksen keskeyttää kuin tyhjästä ilmestyvä koppalakkinen miliisi, joka vaatii veroa maksuun taskulaskimen kanssa. Sama homma toistuu hotellihuoneessa, kun sankari tulee tapaamaan sängynreunalla odottavaa tyttöystävää. Tyttö on kuitenkin mukana miliisin juonessa, ja iloiset koppalakkimme ilmestyvät päätään puistellen ${ }^{11}$ paikalle, tällä kertaa vaatekaapin oven takaa. On jälleen maksun aika.

Sankarilta on kohta kaikki rahat viety ja hän ostaa viimeisillä kolikoillaan juustopiirakan. Miliisikaksikko tulee paikalle ja verottaa senkin omiin suihinsa. Viimeisessä kohtauksessa päähenkilö istuu kadulla kerjäämässä, mutta verottaja iskee jälleen ja tyhjentää kerjuuhatun puti puhtaaksi. Tämän jälkeen verottajakaksikko viskaa lakkinsa maahan, puistelee päätään ja poistuu paikalta valtavaa taskulaskinta näppäillen ja hokien: super, super (hienoa, loistavaa).

Tässä videossa kuvakomposition toinen taso koostuu laulajasta, joka insertoidaan säännöllisin väliajoin kuvatarinan otosten väliin. Hän laulaa paikallaan ja on eräänlaisen bardin tai griotin roolissa. Artisti ei ole lainkaan mukana kuvanarraatio-osuudessa. Insertit noudattavat hyvin laulun jaksotusta ja ovat synkronissa musiikin rytmin kanssa.

\section{Musiikkilähtöinen video}

Musiikkilähtöinen tai ei-narratiivinen kuvarakenne perustuu kestoltaan hyvin lyhyisiin leikkauksiin. Videokuvan ensisijaisena tehtävänä on tukea musiikin rakennetta ja sanomaa. Onnistuneimmillaan MTV-tyylinen kuvatykitys muuttuu musiikin jatkoksi, rytmiseksi kuvamusiikiksi. Tuolloin kuvarytmi voi olla jopa musiikin rytmiä monimutkaisempaa. Bulgarialaisista videoista vain muutamat yltävät tällaiseen 'kokonaistaideteos'-ihanteeseen. Syykin on ilmeinen. Videot tehdään hyvin pienellä budjetilla, mikä suosii erityisesti konserttitaltiointeja, mutta myös narratiivisten videoiden tuotantoa (vrt. Fenster 1993, 119-120). Kannattaa muistaa että myös suomalainen videotuotanto suosii kertomuksia - asiantuntijoiden mukaan suurimpana syynä tähän on juuri pienten markkinoiden rajalliset tuotantobudjetit (A.-V. Kärjä, sähköpostikeskustelu 15.1.2001)

Suuri osa ei-narratiivisista tshalgavideoista on jonkinlaisia sekamuotoja MTV-tyy-

\footnotetext{
${ }^{10}$ Alkupalojen ja pikkunaposteltavan yleisnimi Balkanilla.

${ }^{11}$ Pään puistelu sivusuunnassa tarkoittaa Bulgariassa myöntöä eikä kieltoa, joten tässäkin tapauksessa miliisit eivät paheksu sankarin touhuilua, vaan haluavat sanoa, että hyvä, hyvä, kyllä mekin tästä hyödytään.
} 
lin ja vanhakantaisen estradityylin välillä. Kehitys on kuitenkin menossa kansainvälisempään suuntaan, ja joissakin uusimmissa tshalgavideoissa hyödynnetään onnistuneesti digitaalisen videotekniikan mukanaan tuomia efektejä, kuten osittain pyyhittyjä tai ilmassa liitäviä ihmishahmoja.

Hyvä esimerkki musiikkilähtöistä tyyliä lähentelevästä videosta on laulajatar Sashkan hitti vuodelta 1997, Levovite v marki (Levat markoiksi). Teos on hyvin disko-henkinen komppia myöten; tempo on napatanssia selvästi nopeampi (M. M. 117), ja säestysrytmissä on sekoitettu taitavasti teknotyylin jumputtava galoppi kjutshek-rytmin elementteihin. Tekno-tshalga tuntuisi eroavan teknon globaaleista malleista juuri siinä, että rytminen säestys ahdetaan hyvin täyteen. Samalla päästään leikittelemään diskotanssin ja napatanssin ristiriitaisilla sivumerkityksillä (Esim. 4).

Esimerkki 4. "Levovete v marki", rytminen säestys.

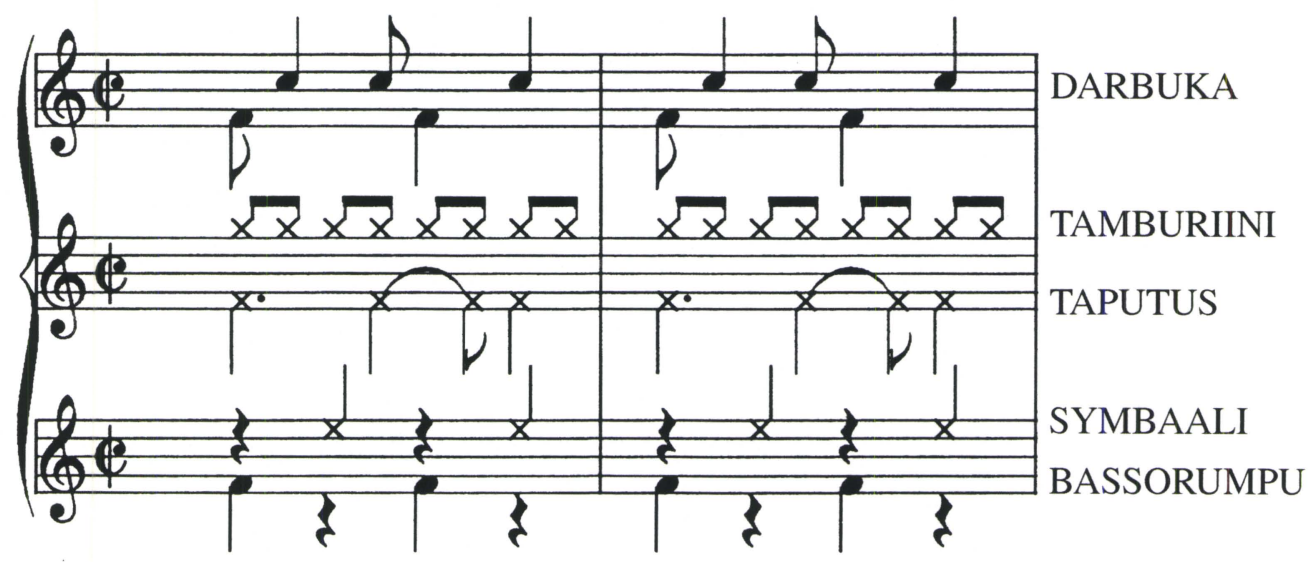

Kuvaleikkaus on normaaliin tshalgatuotantoon verrattuna hyvin nopea. Teoksessa ei ole kertomusta, vaan solistin puolivartalokuva liikkuu oikealta vasemmalle ja päinvastoin, samalla kun kuvarytmi syntyy lyhyillä välähdyksillä puolialastoman pojan ja tytön tanssiosuudesta. Tanssipojan torsoa on leikelty digitaalisesti.

Kaikesta huolimatta teos on hyvin tyypillinen tshalga. Verse-melodia korostaa edellä selostetulla tavalla hicaz-tetrakordia C-Db-E-F, ja kertosäkeessä tonaalinen keskus siirtyy F-säveleeseen laskevan sointukulun f-Eb-Db-C myötä (Esim. 2.). Myös lauluteksti paljastuu sangen poliittiseksi, kun se suhteutetaan bulgarialaisen yhteiskunnan ongelmiin. 


\title{
Tshalgan poliittisuus
}

Kansainväliseen tuotantoon verrattuna monet bulgarialaiset tshalgavideot ovat silmiinpistävän poliittista musiikkia. Tämä ei silti tarkoita, etteikö tshalga noudattaisi kansainvälisen mediaviihteen konventioita. Myös Bulgariassa suurin osa artisteista liikkuu videoissa poplaulujen perinteisillä alueilla, kuten ihmissuhdeasioissa, romanttisessa rakkaudessa, erotiikassa ja muissa päiväunelmissa. Mutta melko monelta laulajalta löytyy kappale, jossa kommentoidaan bulgarialaista arkea ja ongelmia hyvinkin suorasukaisesti. Edellä kuvatussa Sashkan videossa poliittisuus tosin tuntuu aluksi kaukaa haetulta, laulaja tuntuu vain haluavan juhlia:

\author{
Kuule, kuule rakkaani \\ kuule minun pyyntöni \\ Että tänä iltana voisin juopua \\ Levat markoiksi vaihdan mä \\ jotta voisin juoda nyt viiniä \\ Dollarit käyvät, levat ei \\ jos humallun niin tapahtukoon se sitten dollareissa
}

Sinulla ei ole, sinulla ei ole rahaa rakkaani

sinulla ei ole markkoja, dollareita

Nykyään on kauheaa, on synkkää,

jos sinulla ei ole rahaa.

Mutta että laulaisin ja joisin koko päivän,

se ei käy.

(käännös: Ilkko Suvilehto)

Tekstiin sisältyy näin kriittinen kommentti maan taloudellista tilannetta kohtaan. Ilman dollareita tai (Saksan) markkoja kukaan ei ole Bulgariassa mitään, pojalta jāä tyttö saamatta, ja tytön on suunnattava lempensä paksulompakkoisille miehille. Kannattaa vielä muistaa, että video on vuodelta 1997, jota ennen Bulgarian talous kävi pohjamudissaan, lähes kaikki pankit menivät konkurssiin ja levan arvo saattoi laskea jo yhden viikon aikana kymmeniä prosentteja (Kessi 2001).

Tshalga-videoiden kommentoimat yhteiskunnalliset ongelmat liittyvät yleensä korruptioon, taloudelliseen epävarmuuteen ja kansalaisoikeuksiin. Samat aiheet ovat jatkuvasti esillä myös Bulgarian mediassa - onhan Bulgaria nykyisin demokraattinen maa, jossa sananvapaus on laajaa. Kun näitä teemoja vähänkin sivutaan videoissa, koko esityksestä tulee poliittinen.

Termillä poliittinen tarkoitan tässä yhteydessä kaikkia sellaisia ilmauksia ja ilmiöitä, jotka liittyvät kulttuurisiin valta- ja alistussuhteisiin. ${ }^{12} \mathrm{Ne}$ voivat siten olla yhteis-

\footnotetext{
12 Tarja Rautiaisen $(2001,26)$ mukaan politiikka on "ennen kaikkea kamppailua merkityksistä", jotka liittyvät valta- ja alistussuhteisiin. Oma näkökulmani ei kuitenkaan ole diskurssianalyyttinen, joten merkityskamppailuista puhuminen olisi tässä työssä hieman harhaajohtavaa.
} 
kunnallisia kysymyksiä, mutta myös yksilöiden ja ryhmien välisiin suhteisiin liittyviä (sukupuolisuhteet, paternalismi, naisemansipaatio, sukupuoliset vähemmistöt, sukupolvikysymykset). Hyvin suosittuja videoteemoja tuntuvat olevan toisaalta yhteiskunnan vallankäytön epäselvyydet, kuten poliitikkojen ja järjestäytyneen rikollisuuden väliset suhteet ja siihen liittyvä korruptio. Toisaalta taas monissa videoissa nostetaan esille balkanilainen macho-käyttäytyminen, kuten miehinen pullistelu, naisen esineellistäminen ja avoin väkivalta.

Analysoin seuraavassa toisen esimerkin avulla, miten tshalga-video kommentoi ja haastaa yleisenä puheenaiheina olevia poliittisia kysymyksiä. Kappaleen nimi on Zhega (Helle), joka on Valentin Valdesin tuotantoa vuodelta 1997. Valdes on edellä mainitun Petran ohella ehkä kaikkein eniten suuntautunut vallankäytön ja yhteiskunnallisten kysymysten kommentointiin ja irvailuun. Laulujen kritiikki on hyvin suoraa, mutta ristiriitaista. Länsimaisen feminismin näkökulmasta Valdesin laulut saattavat vaikuttaa kerrassaan röhkivältä sovinismilta. Ne eivät missään tapauksessa ole poliittisesti korrekteja, vaan melkoisen karkeita. ${ }^{13}$ Ristiriita näkyy jo laulajan imagossa: hän näyttää hieman kaljuuntuneelta ja tukevoituneelta mafiamieheltä ja näyttelee tässä videossaan myös vastaavassa roolissa. Lisäksi Valdes on tunnettu raflaavista kasetinkansistaan, joiden pääkuvana on erittäin vähäpukeinen tyttö poseeraamassa Playboy-lehden alastonmallien suosimissa asennoissa.

Napatanssirytmissä etenevä laulu on siinä mielessä poikkeava, että sen melodiikka on lähes koko ajan miksolyydinen - duuri pienellä septimillä. Itäinen vire tulee jälleen kappaleen keskiosan pitkällä improvisaatiojaksolla, jossa monista videoista tuttu syntetisaattorin tshalgasaundi piirtää pitkää koristeellista melodiaa. Myös solisti laulaa laulusäkeistöjen välissä alaspäin liikkuvan soolohuikaisun, joka viiden tahdin mittaisena kontrastoi teoksen muuten symmetristä rakennetta.

Zhega-videon kuvakerronta jäljittelee road movie -perinnettä. Artisti on tässä narratiivisessa kappaleessa sekä laulaja että kuvakerronnan pääroolissa. Juoneen sisältyy kaahaamista ja takaa-ajoa länsimaisilla autoilla (BMW ja Alfa Romeo), ammuskelua, pimeitä kauppoja sekä poliisien ja tullin lahjontaa - koppalakeilla on tietenkin Lada. Lauluinserteissä sankari tanssi diskoteekissa napatanssia nuorien tyttöjen kanssa, sisältyypä kuvakerrontaan myös tyttöystävän pahoinpitelyä ja lineaarista polygamiaa (parinvaihtoa). Kaiken kaikkiaan Valentin Valdes on melkoisen öykkärin roolissa, miehen jonka käskyjä totellaan ja jota pelätään.

Ostin itselleni BMW:n, ostin jee

pistän perseeni nyt baariin

Jos joku koskee mun bemariin,

hän tulee pelkäämään 'every day'

${ }^{13}$ Eri asia sitten on, vastaako länsimainen käsitys korrektisuudesta bulgarialaista standardia. Eräs ystäväni Sofiassa kommentoi asiaa näin: "Miksi meidän pitäisi olla poliittisesti korrekteja, kun jokapäiväinen elämäkin on kaikkea muuta kuin korrekti?" 


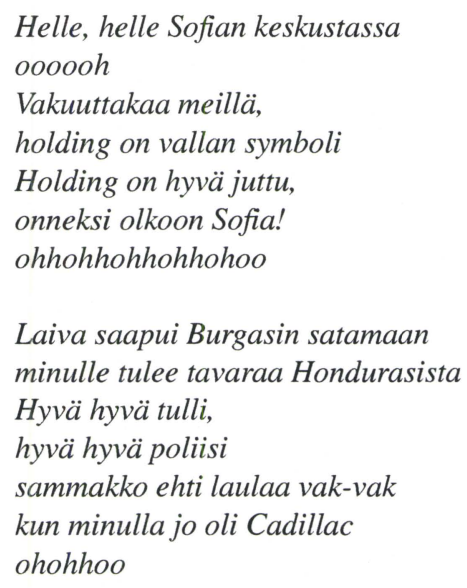

Helle, helle Sofian keskustassa oooooh

Älä kysy minulta kuka olen, vaan kysy paljonko minulla on valtaa Kolme vuotta perättäin tulen olemaan pääkaupungin pormestarina ohhohhohhohhoo

Minusta sanotaan:

hän on kyllä pätevä muttei sopiva, tiedän sen

En liikauta peukaloakaan, tiedä se, jos et maksa käteisellä Holding on hyvä juttu, onneksi olkoon Sofia! ohhohhohhohhohoo

(käännös: Ilkko Suvilehto)

Kertosäkeessä toistuva ylistys holdingille nostaa kysymyksen: mikä ihmeen holding? Holding tulee ilmeisesti sanoista holding company ja viittaa yksityisiin mafian omistamiin pankkeihin ja vakuutusyhtiöihin, jotka olivat 1990-luvun puolivälissä jatkuvana puheenaiheena Bulgarian medioissa. Näistä yhtiöistä suurimpia olivat VIS-2 ja SIC, ja niiden toiminta perustui erittäin näkyvään mainontaan ja vielä aggressiivisempaan markkinointitapaan. Bisneksen kohteena oli kuka tahansa, jolla oli näkyvää omaisuutta, kuten auto, taide-esineitä, liikehuoneisto tai omakotitalo. Yhtiön metodina oli lähettää myyntimies potentiaalisen asiakkaan luo kertomaan, kuinka edullista vakuutuksen otto olisi. Jos asiakas ei vihjeestä ymmärtänyt, lähetettiin firman pojat myöhemmin särkemään vaikka kioskin ikkuna tai suorittamaan luvatonta käyttöönottoa potentiaalisen asiakkaan autolle. Viimeistään tämän jälkeen uhri saatiin uskomaan vakuutuksen autuaaksi tekevä vaikutus. (Nikolov 1997.) 
On väitetty että holding-yhtiöiden vakuutustoiminta oli vain yksi rahanpesukeino, jolla Bulgarian mafia pyrki tekemään laittomat ansionsa laillisiksi. Vuosina 19941997 maata hallinnut sosialistihallitus (entiset kommunistit) eivät saaneet tätä toimintaa loppumaan. Siihen tarvittiin vallanvaihdos, jonka jälkeen uusi oikeisto-liberaalinen Kostovin hallitus hyvin nopeasti teki edellä kuvatun vakuutustoiminnan laittomaksi ja ne hävisivät julkisuudesta. On myös epäilty, että sosialistista hallitusta lähellä olevia poliitikkoja ja virkamiehiä olisi sotkeutunut vakuutuskauppoihin. Tämä tausta selittää Zhega-videon loppupuolella olevan tekstin, jossa laulaja-mafioso kerskailee tulevasta urastaan Sofian pormestarina. (Anon. 1997.)

\section{Tshalga ja orientalismin kritiikki}

Stereotyyppiset viittaukset itään tuntuvat olevan tshalgan suosion takana. Se antaa aiheen olettaa, että tshalgan tuotanto ja vastaanotto olisivat osa orientalismia, joka on vaikuttanut länsimaiden taiteessa ja viihteessä jo vuosisatoja. Orientalismin yhdistäminen Bulgariaan kuulostaa silti äkkiseltään melko ristiriitaiselta, kun otetaan huomioon orientalismi-käsitteen sisältö, Bulgarian maantieteellinen sijainti ja kulttuurihistoriallinen menneisyys. Orientalismin historia ja sen nykyinen kritiikki painottavat ainakin kolmea asiaa, jotka eivät oikein sovi Bulgariaan. Ensinnäkin orientalismilla tarkoitetaan nimenomaan länsimaisen kulttuurin suhdetta itäiseen tai toisinpäin ilmaistuna: Idän kulttuuriperinnön reprensentaatiota länsimaissa. Orientalismi kertookin enemmän läntisestä ihmisestä kuin Idän kulttuureista. (Scott 1997, 9; Said 1995, 21.) Toiseksi orientalismin pohjana on itäisen kulttuurin vieraus. Itä on ollut (Länsi)Euroopan ja Pohjois-Amerikan kansoille ja valtioille aivan oikeasti se outo Toinen, jota koskevat käsitykset ovat perustuneet enemmän kuvitelmiin kuin konkreettiseen tietoon ja kulttuurikontaktiin. Kolmanneksi orientalismi on pohjimmiltaan länsimaisen ihmisen ylemmyydentunnon historiaa. Käsitteeseen sisältyy implisiittisenä näkemys Idästä epävarmuuden, kaaoksen, väkivallan ja tehottomuuden maailmana. Näkemykset ovat säilyneet vuosisadasta toiseen mm. kirjallisuuden, taiteen ja matkakertomusten luomina stereotypioina. (Said 1995, 6-7; 300-301.)

Saidin tulkinta liittää orientalismin suoraan kolonialismin historiaan sekä jälkikolonialistiseen mediakritiikkiin. Orientalismi nähdään tällöin yhtenä tehokkaana keinona, jonka avulla ei-länsimainen kulttuuri on valjastettu osaksi valkoisen miehen hegemonian ylläpitoa. Orientalismi on taannut sen, että Itä on aina pysynyt alempiarvoisena länteen verrattuna. Itää on myös haluttu tarkastella ainoastaan länsimaisen kokemuspiiriin suhteutettuna. Orientalismi ei ole antanut sille itsenäistä olemassaolon oikeutta. Näyttää kuitenkin siltä, että saidilainen orientalismitulkinta sopii verraten huonosti Bulgarian tshalgaan. Kaikki olennaiset attribuutit ja kytkökset kääntyvät helposti päälaelleen. 
Bulgaria on todella Idän kynnyksellä. Sen itärajalta on reilu 200 kilometriä Istanbuliin, tuohon orienttimyytin ehkä tärkeimpään keskukseen, mihin suuri osa Osmaniimperiumia koskevia mielikuvia paikallistuu. Aivan Bulgarian rajan pinnassa on Edirne, entinen Adrianapoli, strategisesti tärkeä varuskuntakaupunki, jonka läpi osmanien jokavuotiset sotaretket Eurooppaan säännönmukaisesti kulkivat (Wheatcroft 1995, 52). 1900-luvun Bulgarian itäisyyden ylläpitäjänä on pidettävä myös sitä, että maa kuului vuosina 1944-1989 kiinteänä osana neuvostoimperiumiin. Kylmän sodan vuosina Neuvostoliitto oli paitsi poliittisesti Lännen vastakohta, myös eräänlainen uusorientalismin kohdealue. Myös siihen kohdistui länsimaisessa julkisuudessa ja länsimaisen ihmisen mielikuvissa sellaisia stereotypioita, jotka ovat tuttuja klassisen orientalismin kaudelta: tehottomuus, julmuus, irrationaalisuus, pahuus, salaperäisyys. Bulgarialaisessa keskustelussa klassiseen orientalismiin ja neuvosto-orientalismiin liitettävät selitysmallit näyttävät sekoittuvan mielenkiintoisalla tavalla.

Bulgaria oli alusmaa osmanivaltakunnan ytimessä ja myöhemmin Neuvostoliiton kurinalaisin vasalli. Lyhyehköä kuningaskunnan aikaa (1879-1944) lukuun ottamatta maa on suuntautunut enemmän itään kuin länteen, ja se näkyy hyvin monessa bulgarialaisen kulttuurin piirteessä. Myös viime vuosien poliittinen kehitys näyttää suosivan Bulgarian orientoitumista itään, koska Balkanin monimutkaisessa valtiopolitiikassa Turkki ja Bulgaria näyttävät löytäneet toisensa. Vanhat etnisiä vähemmistöjä koskevat kiistat näyttävät siirtyneen historiaan, ja maiden välinen kauppa on kasvanut moninkertaiseksi. Tämä koskee mitä suurimmassa määrin myös musiikkiteollisuutta: esimerkiksi valtaosa maassa käytettävästä kasettien raaka-aineesta tuodaan itäistä reittiä. Istanbul, alueen suurin metropoli, on muuttumassa jälleen bulgarialaisten Tsarigradiksi, Keisarin kaupungiksi. (Suvilehto 1999, 153-156; Ivo Dotshovski, haastattelu 1999)

Lähentyminen Turkkiin on tietenkin pääasiassa alueellista valtapolitiikkaa, eikä itään suuntautuminen merkitse tässä tapauksessa mitään muuta kuin pelkkää ilmansuuntaa: tälläkin kytköksellä on pääasiassa läntinen sisältö. Kaikkien Balkanin valtioiden - ja myös Turkin - tavoin Bulgarian suurin poliittinen tavoite on integroituminen läntiseen Eurooppaan eli EU:hun. Virallinen Bulgaria on ollut varsinkin 1997 valtaan nousseen oikeisto-liberaalisen hallinnon aikana silmiinpistävän länsimielinen. Sama koskee maan yleistä ilmapiiriä, jossa hyvin tyypillinen keskustelun ja jopa mielenosoitusten aihe on ollut viisumivapauden saaminen Schengen-maiden kanssa. Nämä länsimaistumistoiveet yhdistettyinä itäiseen menneisyyteen muodostavat joka tapauksessa perimmäisen syyn siihen, miksi orientalismi kaikesta huolimatta on pätevä lähtökohta bulgarialaisen nykykulttuurin analyysiin. Tarvitaan vain sopiva orientalismin tulkinta, eikä se tunnu löytyvän postkolonialistisesta kirjoittelusta.

Orientalismissa on kuitenkin yksi piirre, joka voisi postkolonialistista teoriaa paremmin selittää sen suosion niin Balkanilla kuin myös muilla idän ja lännen välisillä kulttuurialueilla (esimerkiksi Venäjällä, Ukrainassa ja Romaniassa ja epäilemättä myös Suomessa). Orientalismi on erottelun, distinktion väline. Vaikka itäinen kulttuuri on 
lähellä, siihen voi tehdä selvän eron orientalismin avulla. Itäinen kulttuuri ei tule siinä esiin todellisena ja vakavana, vaan sadunomaisena, leikillisenä ja myyttisenä kertomuksena. Koska itäisyys ei ole todellista, siihen sitoutuminen ei ole myöskään todellista. Orientalistinen suhde Itään merkitseekin paradoksaalisesti Idän kieltämistä ja viime kädessä oman länsimaisuuden vahvistamista.

Samaan suuntaan vaikuttaa se karnevalistinen perusvire, joka liittyy moniin Itämyyttiä hyödyntäviin kulttuurin tuotteisiin. Ei ole sattumaa, että Balkanilla kuten myös Venäjällä ja Keski-Euroopassa juuri mustalaiset ovat olleet orientalismin keskeisiä tuottajia tai kohteita niin musiikissa, kirjallisuudessa kuin kuvataiteissa. Mustalaiset edustavat väestönosaa, joka ei kiinnity mihinkään. Heillä ei ole selvästi määriteltyä paikkaa modernissa kansallisvaltiossa, ja sen vuoksi he sopivat mainiosti kuvitteellisen itämaisuuden edustajiksi. Erityisesti venäläisessä perinteessä mustalaiset ovat olleet vuosisatoja myyttinen kulttuurinen lokero, joka on sallinut karnevalistisen toiminnan. Venäläisessä kirjallisuudessa ja tarinoissa mustalaiset ovat aina läsnä, kun sankarit haluavat unohtaa arkipäivän, juhlia ja juopotella, pelata ja tuhlata: sanalla sanoen kun yhteisön arvot käännetään nurinniskoin. (Broms 1984, 159; Crowe 1996, 164-169.) Ei ole lainkaan epätodennäköistä, etteikö tämä sama stereotypia toimisi myös Balkanilla. Itse asiassa väitän, että juuri siinä on tshalgamusiikin ja -videoiden suosion tärkeä nykypäivän Bulgariassa.

Karnevalistinen suhtautuminen kuuluu muutenkin uusien tshalgalaulujen perustekniikkaan. Vakavien asioiden esittäminen pilkkana, itseironiana tai monimielisinä vihjauksina sopii hyvin teksteihin, jotka puuttuvat poliittisesti arkaluonteisiin ilmiöihin. Itse asiassa poliittinen parodia on usein huomattavasti tehokkaampaa kuin julistava ja vakava poliittisuus. Kevyessä musiikissa poliittisesti arkaluonteisten asioiden esittämiselle ei juuri muuta keinoa olekaan. Heti kun tyyli muuttuu vakavaksi julistukseksi, musiikin keveys katoaa. Marseljeesi, Internationaali tai Horst Wessel ovat epäilemättä populaarimusiikkia, mutta on varmasti aivan oikein olla käyttämättä niistä termejä pop, kevyt musiikki tai viihde.

Yhteenvetona voi todeta, että orientalismi merkitsee bulgarialaisille selvästi eri asiaa kuin länsieurooppalaisille tai amerikkalaisille. Se ei pohjaudu kolonialistiseen menneisyyteen siinä mielessä, että alistamisen suunta olisi lännestä itään. Päinvastoin, kolonialismi on tarkoittanut Bulgariassa sitä, että itäiset imperiumit ovat alistaneet ja hyväksikäyttäneet bulgarialaisia: ensin osmanit ja sitten Neuvostoliitto. Osmanivallan perintö kääntää orienttipiirteisen populaarimusiikin merkitysmaailman plusmerkkiseksi - saidilaisen orientalismi-kritiikin negatiiviset konnotaatiot katoavat. Tshalga on vapautumisen ja erottautumisen musiikkia, joka ei pidä kulttuurista Itää pilkkanaan tai alempiarvoisena. Tshalgan itämaisuus on bulgarialaisille itseironian lähde. Se auttaa oman identiteetin ymmärtämisessä. Lisäksi se auttaa irtautumaan kansallisvaltion synnyttämän kulttuurisen eliitin hegemoniasta tai ainakin suhtautumaan ylistettyyn kansalliskulttuuriin kriittisesti. Viime kädessä tshalga-orientalismi heijastaa ja koros- 
taa paradoksaalisesti vastakohtaansa, kulttuurin länsimaistumista. Kun itäiset sankarit ja satuolennot rikkauksineen ovat vaihtuneet mafian liikemiehiin ja läntisiin ylellisyystavaroihin, toisin sanoen amerikkalaiseen utilitarismiin, ironian kohteena ei olekaan itä vaan länsi ja siihen liittyvät päiväunet.

\section{Lähteet}

\section{Musiikkivideot}

Dj Folk Collection 6 plus. Payner 2000.

Duo Juzhen polàh i gosti: Ah, zheni. Folkton i.v.

Hitovete na Mustafa Tsajshev. Perfekt Video i.v.

Kanarite s ljubov i nastroenie. Payner 1999.

Kozari: Kapàlà Tsharshija. Payner 1995.

Kristal i prijateli. Perfekt Video i.v.

Kristali: More ot ljubov. Payner 1995.

Marin Dzhambasov i ork "Knezha": Metshtata na shejha. Lazarov rekàrds i.v.

Payner Hit Video 1. Video Hit Collection. Payner 1996.

Payner Hit Video 6. Payner 1999.

Payner Hit Video 7. Payner 2000.

Payner Hit Video 8. Payner 2000.

Petra: Hishna hiena. Payner 1999.

Pirin Folk '95. Festival Sandanski. Electroimpex Simex i.v.

Sashka Vaseva: Prikazka za vljubeni. Multi video tsentàr 1997.

Sasho Roman: Bez upojka. BMK kompanija i.v.

Zvezdite na Trakija Folk 1994. Payner 1995.

\section{Kirjallisuus}

Alanen, Antti \& Ilppo Pohjola 1992. Sähköiset unet - miten taiteesta tuli pop. Helsinki: VAPK-Kustannus.

Anon. 1997. Law Enforces Corner Shady Businesses. Bulgarian Telegraph Agency (BTA), 97-03-11, [5]. http://www.hri.org/news/balkans/bta/97-03-11.bta.html

Broms, Henri 1985. Alkukuvien jäljillä. Kulttuurin semiotiikkaa. Porvoo - Helsinki - Juva: WSOY.

Buchanan, Donna 1995. Metaphors of Power, Metaphors of Truth: The Politics of Music Professionalism in Bulgarian Folk Orchestras. Ethnomusicology Vol.39, No.3, ss. 381-416.

Buchanan, Donna 1996. Wedding Musicians, Political Transition, and National Consciousness in Bulgaria. Retuning Culture: Musical Change in Central and Eastern Europe, toim. Mark Slobin. Durham - London: Duke University Press. Ss. 200-230.

Crowe, David 1996. A History of the Gypsies of Eastern Europe and Russia. New York: St Martin's Griffin.

Feldman, Walter 2000. Music of the Dancing Boys. Lalezar - Music of the Sultans, Sufis \& Seraglio, Vol II. Oheisvihko saman nimiseen äänitteeseen. New York: Traditional Crossroads.

Fenster, Mark 1993. Genre and Form: The Development of the Country Music Video. Sound and Vision - The Music Video Reader, toim. Simon Frith \& al. London and New York: Routledge. Ss. 109_ 128.

Frith, Simon 1988. Music for Pleasure. Essays in the Sociology of Pop. Cambridge: Polity Press.

Ghodsee, Kristen 2000. Women and Economic Transition: Mobsters and Mail-Order Brides in Bulgaria. Center for Slavic and East European Studies Newsletter Fall 2000, Vol.17, No.3. Berkeley: University of California, ss. 5-13. http://socrates.berkeley.edu/ iseees/ 
Huotari, Markku 1999. Flamencomusiikin taustaa. Flamenco, toim. Katja Lindroos. Jyväskylä: Like Kustannus. Ss. 98-129.

IFPI Music Piracy Report 2000. http://www.ifpi.org

Kessi, Alain 2001. Global Mobilizations - What are the protests in Prague all about? Liquidation of the economy and new dependancies - the example of Bulgaria. Farce Academy for Applied Applications: Studium Generale, No 4. http://www.copyriot.com/unefarce/no4/prag-en.html

Kurkela, Vesa 1996. Piraatit, orientalismi ja poliittinen epäkorrektisuus. Näkymiä Itä-Balkanin musiikkikulttuuriin. Musiikin Suunta 2/1996, ss. 36-51.

Kurkela, Vesa 1997. Music Media in the Eastern Balkans: Privatised, Deregulated, and Neo-Traditional. Cultural Policy, Vol. 3, No 2, ss. 177-205.

Manuel, Peter 1993. Cassette Culture. Popular Music and Technology in North India. Chicago - London: The University of Chicago Press.

MacKenzie, John M. 1995. Orientalism. History, Theory and the Arts. Manchester - New York: Manchester University Press.

Music industry acts on Ukraine, Europe's new pirate haven. http://www.ifpi.org/press/19990721.html

Nikolov, Jovo 1997. Crime and Corruption after Communism. Organized Crime in Bulgaria. East European Constitutional Review, Vol.6, No.4. http://www.law.nyu.edu/eecr/vol6num4/feature/organizedcrime.thml

Pennanen, Risto Pekka 1999. Westernisation and Modernisation in Greek Popular Music. Acad. diss. Acta Universitatis Tamperensis 692. Tampere: Tampereen yliopisto.

Pennanen, Risto Pekka 2001. Folk Music Research and Nationalism in the People's Republic of Bulgaria: a Preliminary Analysis. Zbornik radova II. mežnarodni simpozij "Muzika u društvu", toim. Ivan Cavlović. Sarajevo: Musikološko društvo FbiH. Ss. 173-183.

Pettan, Svanibor 1996. Gypsies, Music, and Politics in the Balkans: A Case Study from Kosovo. The World of Music 38(1), ss. 33-61.

Poulton, Hugh 1991. The Balkans. Minorities and States in Conflict. London: Minority Rights Publications.

Rasmussen, Ljerka Vidic 1991. Gypsy Music in Yugoslavia: Inside the Popular Culture Tradition. Journal of the Gypsy Lore Society 5, Vol 1, No.2, ss. 127-139.

Rautiainen, Tarja 2001. Pop, protesti, laulu. Korkean ja matalan murroksia 1960-luvun suomalaisessa populaarimusiikissa. Tampere: Tampere University Press.

Said, Edward W. 1995 (1978). Orientalism. Western Conceptions of the Orient. London: Penguin Books.

Scott, Derek B. 1997. Orientalism and Musical Style. Critical Musicology Journal. A Virtual Journal on the Internet. http://www.leeds.ac.uk/music/Info/CMJ/Articles/1997/02/01.html

Seeman, Sonia 2000. The Road to Keșan. Turkish Rom and Regional Music of Thrace. Oheisvihko samannimiseen äänitteeseen. New York: Traditional Crossroads CD 6001.

Silverman, Carol 1996. Music and Power: Gender and Performance among Roma (Gypsies) of Skopje, Macedonia. The World of Music 38(1), ss. 63-76.

Stefanova, Julia i.v. The Empirical Reader in a Virtualized Reality. Reading in the Age of Media, Computers, and Internet. Conference Abstracts. http://www.liternet.revolta.com/iser/iustef1.htm

Suvilehto, Ilkko 1999. Bulgaria Balkanin eteläisessä kolmiossa: muutos. Balkan 2000. Näkökulmia ja taustoja Kaakkois-Euroopan nykytilanteelle, toim. Vesa Saarikoski. Turku: Turun yliopiston poliittisen historian tutkimuksia 17. Ss. 139-162.

Thiam, Riitta 1999. Orientalismikriittinen ja postkolonialistinen näkökulma suomalaiseen musiikkiin. Musiikki 4/1999, ss. 391-415.

Wheatcroft, Andrew 1995. The Ottomans. Dissolving Images. London - New York: Penguin Books. 